GLOBAL JOURNAL OF EDUCATIONAL RESEARCH VOL 15, 2016: 79-87

COPYRIGHT@ BACHUDO SCIENCE CO. LTD PRINTED IN NIGERIA. ISSN 1596-6224

\title{
THE EFFECT OF TRAINING ON TEACHERS' KNOWLEDGE OF EFFECTIVE CLASSROOM MANAGEMENT STRATEGIES IN JOS METROPOLIS
}

\section{KATRINA A. KORB, GRACE SELZING-MUSA AND SWANTA BLESSING SKINNER-BONAT}

(Received 8, September 2015; Revision Accepted 23, November 2015)

\begin{abstract}
The purpose of this study was to determine the effectiveness of in-service training on teachers' knowledge of effective classroom management strategies. Twenty teachers from Jos metropolis participated. A single group pre-post test design was used, with a one-day training on classroom management techniques as the independent variable and the number of strategies that teachers suggest as effective for managing student behavior as the dependent variable. An open-ended structured interview was used to measure the dependent variable. The study found that the number of strategies that teachers believe are effective for classroom management was significantly higher after the training, indicating that the training was effective in improving teachers' knowledge about classroom management. Specifically, the number of proactive strategies that teachers believed were effective for classroom management significantly increased after training, whereas the number of reactive strategies remained unchanged. Thus, teachers' knowledge about effective classroom management strategies can be effectively modified by a brief, one-day in-service training.
\end{abstract}

KEYWORDS: Classroom Management, Discipline, In-service training, Misbehavior, Classroom Environment

\section{INTRODUCTION}

One of the basic factors that contribute to meaningful and effective learning is the ability of the teacher to effectively control the classroom environment. Classroom management is defined as strategies that create and maintain an orderly learning environment (Eggen \& Kauchak, 2004). Classroom management is important because it influences learners' achievement (Yount, 1996) and helps learners develop responsibility and self-regulation to avoid unnecessary disruptions in studying (Slavin, 2006). Indeed, one of the most important roles of a teacher is to manage the classroom well (Marzano, Marzano, \& Pickering, 2003).
In a meta-analysis of 50 years of research, Wang, Haertel, and Walberg (1993/94) cited classroom management as the seventh most influential factor that affects student learning. Indeed, classroom management was found to be even more important in student learning than the home environment, peer group, and community influences. Wang and colleagues reported that effective classroom management increases student engagement in the learning process, decreases disruptive behaviors, and enables teachers to make effective use of limited instructional time.

A classroom is effectively managed by the manner in which the teacher exercises authority, shows warmth and support, and

Katrina A. Korb, Department of Educational Foundational, University of Jos, Jos, Plateau State, Nigeria.

Grace Selzing-Musa, Department of Educational Foundational, University of Jos, Jos, Plateau State, Nigeria.

Swanta Blessing Skinner-Bonat, Shepherdsfield Academy, Jikwoyi, Abuja 
encourages cooperation amongst the students. Thus, the management of the classroom is the teacher's responsibility (Borich, 2007).A teacher that desires successful learning is saddled with the responsibility of being creative in employing ways that will help in bringing about a positive learning environment. This positive atmosphere is achieved when there is minimal misbehavior in the classroom as a result of using the proper strategies in reducing such learner misbehavior.

One aspect of effective classroom management is effectively handling student misbehavior. Managing misbehavior is a chronic problem for teachers (Eggen \& Kauchak, 2004). Tauber (2007) reports that lack of student discipline is one of the biggest problems that public schools face. Managing discipline problems takes a significant portion of classroom instructional time, which interferes with the learning process. Curwin and Mendler (1984) estimate that this lost instructional time results in 15 to 25 percent of the total classroom time. However, there is no single technique that is a panacea for dealing with the problem of student misbehavior (Tauber, 2007). Instead, teachers need a variety of strategies for managing student misbehavior, and understand which strategies are generally more effective than others.

There are two sets of strategies that teachers need to be effective classroom managers. First, teachers can implement strategies to prevent misbehavior from occurring in the first place, such as setting classroom rules and establishing positive teacher-student relationships (Marzano et al., 2003). Second, when students actually do misbehave, there are strategies that teachers can employ to compel students to change their behavior.

\section{Strategies for Preventing Misbehavior}

According to Yount (1999, p. 157), classroom management is:

The process of anticipating, planning for and handling behavior problems in the classroom. Consistent use of management principles produces a positive, well-ordered learning environment. These principles emphasize prevention more than reaction...learner self control more than teacher control..., and a positive rather than a negative atmosphere.
Note that Yount believes that classroom management principles are more tailored towards preventing misbehaviors than dealing with misbehaviors that have already occurred.

Establishing rules and procedures to prevent classroom discipline problems is one of the most important classroom management strategies (Borich, 2007). Classroom rules should be established early in the school term, and be clearly communicated to students so that the students know what is expected in regards to academic work and classroom conduct(Yount, 1999). Students can contribute to the development of rules, which results in students understanding the rules more clearly, and being more compliant because they are more committed to the rules (Curwin \& Mendler, 1984). Additionally, teachers should be consistent when managing behavior problems (Eggen \& Kauchak, 2004).When rules are established at the beginning of the school session, they have to be followed consistently, so that when misbehavior issues arise, they are more easily managed.

Another strategy for preventing misbehavior is to praise good behavior (Slavin, 2006). Positive behaviors should be praised because praise motivates students. Furthermore, praising other students for good behavior can encourage the entire class to behave well.

Teachers can also prevent misbehavior by displaying an attitude of with-it-ness, which means that the teacher demonstrates an awareness about what is going on in every part of the class at the same time (Eggen \& Kauchak, 2004). A teacher with with-it-ness knows when a misbehavior is about to occur and can take preventative action or disciplinary action (van der Sude \& Tomic, 1993).

\section{Strategies for Managing Misbehavior}

Once a student has misbehaved, there are a number of strategies that can be implemented to effectively handle the misbehavior. First, though, teachers should remember that interventions should be kept brief because when intervention is prolonged, it breaks the flow of the lesson and detracts from instruction (Eggen \& Kauchak, 2004). This can be achieved with a nonverbal cue to an erring student (Slavin, 2006). Through nonverbal cues, 
classroom misbehavior can be eliminated without interrupting the concentration of other students. Some of these strategies include making eye contact with the misbehaving student, moving close to the misbehaving student, or lightly putting a hand on the misbehaving students' shoulder.

The teacher can also use repeated reminders or the broken record (Slavin, 2006). This is a repetition of the rule as irrelevant arguments and excuses are ignored. This is a behavior management style where the teacher decides what he wants the students to do, states it clearly to the students and repeats it until the students comply. Teachers can also remind disobedient students about the importance of the rule and how to comply with the rules.

Slavin (2006) suggests that applying consequences is usually the last option in managing misbehavior. A choice is posed to the misbehaving student about whether to comply with a stated rule or face the consequences. Some of these consequences may include sending the student out of the class, making him miss break time, making her lose privileges, or having him stay after school and invite parents to discuss their ward's misbehavior. These consequences, whenever used, must be mildly unpleasant, short in duration of application, and should be applied as soon as a misbehavior occurs.

\section{Purpose of Study}

Marzano and colleagues (2003) propose that effective classroom managers are developed through awareness of and training in effective classroom management techniques. Therefore, the purpose of this study was to determine the effectiveness of in-service training on teachers' knowledge of effective classroom management strategies. To this end, teachers were interviewed about their knowledge of classroom management strategies both before and after a one-day in-service training on classroom management. Their interview responses were coded to identify the presence or absence of 26 specific classroom management strategies.

As Tauber (2007) stated, there is no single technique that is effective for classroom management. Instead, teachers need to have knowledge of a wide range of strategies that both prevent misbehavior and manage misbehavior once it has happened. Therefore, the number of classroom management strategies that teachers mentioned were used to measure teachers' knowledge of effective classroom management strategies, with a higher number of strategies representing more effective knowledge about classroom management. Strategies for preventing misbehavior were termed proactive strategies whereas strategies for managing misbehavior after it has occurred were termed reactive strategies.

\section{Research Questions}

1. What strategies do teachers believe are effective for managing student behavior before training and after training?

\section{Research Hypotheses}

1. There is no significant effect of training on the total number of strategies that teachers suggest for managing student behavior.

2. There is no significant effect of training on the number of proactive strategies that teachers suggest for managing student behavior.

3. There is no significant effect of training on the number of reactive strategies that teachers suggest for managing student behavior.

\section{Methodology}

\section{Research Design}

This research used a single group prepost test design. A pre-test interview was given to teachers on the first of a two-day in-service training. The treatment, in-service training on classroom management techniques, was presented on the second day of training. (The first day of training was unrelated to classroom management, so the in-service training relevant to the purposes of this study lasted one day.) The in-service training was the independent variable. The post-test was conducted three weeks after the in-service training. The dependent variable was the number of strategies that teachers suggested were effective for managing student behavior. These strategies were sub-divided into proactive strategies that prevent misbehavior from occurring and reactive strategies that are used after a student has misbehaved. The 
number of strategies mentioned at the pre-test and post-test were compared.

\section{Participants}

The population for the study consisted of private school teachers in Jos Metropolis at both primary and secondary school levels. A total of 36 teachers attended the in-service training in which the study was conducted. Twenty-four teachers in attendance were selected to participate in the pre-test interview. Three of these teachers were not interviewed at the posttest because they were absent on the second day of training on classroom management. A fourth participant was not included in the final analysis because he admitted during the posttest interview that he was late for the second day of training and therefore did not learn much about classroom management. Thus, a total of 20 teachers who completed both the pre-test and post-test interview constituted the final sample of the study.

The participants were made up of 8 males $(40 \%)$ and 12 female participants (60\%). Their ages ranged from 23 years to 47 years (mean $=33.5$ years). Their educational qualifications ranged from Secondary School Certificate, NCE/Diploma and Degree certificates. One participant had a secondary school certificate $(5 \%), 13$ participants had NCE/Diploma certificates (65\%) and 6 participants had Degree certificates (30\%). Those that had their educational qualifications in Education were 12 while those that did not were $8,60 \%$ and $40 \%$, respectively. The participants' teaching experience ranged between 1 month and 23 years with the mean at 7.5 years of teaching experience. Those who taught at the Nursery school level made up $30 \%$ of the participants, $45 \%$ of the participants taught at the primary school level, while $25 \%$ of the participants taught at the secondary school level.

\section{Instrument}

The instrument used for this study was a researcher-constructed structured interview which sought information on teachers' knowledge about classroom discipline and management of learners' misbehavior. There were 16 openended items on the interview: six were background questions asking about participants' teaching experiences, and ten were related to teachers' knowledge about classroom management. The pre-test and post-test were identical except for two questions. At the pre-test, the researchers asked, "What would you like to learn more about regarding discipline in school?" and "What do you think can be done to help you improve discipline in your school?" At the posttest, these questions were rephrased to "What did you learn from the training about classroom management and discipline?" and "Is there anything you plan on changing in your teaching because of the training? If so, what do you plan on changing?"

\section{Procedure for Data Collection}

The study was conducted in an in-service training for teachers that held toward the end of a mid-term break. The training lasted from 9am through $2.30 \mathrm{pm}$ on two separate days. The pretest was administered on the first day of the training. (The content of the first day of training was unrelated to classroom management.) Participants were taken one-by-one to a quiet room, where researchers explained the purpose of the study and received informed consent from participants. Their answers to the structured interview questions were audio-recorded, and later transcribed word-for-word.

The second day of training constituted the treatment. During the training, teachers were instructed on how best to manage students in the classroom in terms of setting rules and appropriate ways to manage misbehaviors when they occur. Discussion and practical activities were the key methods used in the training. The teachers were encouraged to structure their classrooms and the learning environment as a community. To achieve the community, teachers were encouraged to set rules with the students, help the students set personal goals and strategies for achieving their goals, give students classroom responsibilities, appreciate student's work and celebrate student differences without comparison, and encourage trust and respect for one another in interaction and cooperation. Teachers were also encouraged to build personal relationships with the learners and also manage the classroom through preventive and corrective discipline.

The post-test interview was conducted by visiting the teachers in their various schools three 
weeks after the training. Again, teachers were removed to a quiet room where they completed the interview one-on-one with a researcher. Their responses to the post-test interview were also audio-recorded and transcribed word-for-word.

\section{Method of Data Analysis}

Teachers' responses to the interview questions were analysed using qualitative content analysis. After reviewing teachers' responses to the interview, a list of 26strategies were identified (see Table 1).Eleven strategies were identified as reactive strategies, meaning that a student had already misbehaved and teachers were reacting to that misbehavior. Some examples of reactive classroom management strategies include reminding students of the rules, shouting at the student, beating the student, counseling the student, and consistently enforcing the rules. Thirteen proactive classroom management strategies were identified as ways that teachers can structure their classrooms to try to prevent students from misbehaving. Sample proactive strategies include setting clear rules, providing clear expectations for classroom behavior, closely monitoring students, and getting students actively involved in the lesson. Two additional strategies that were frequently mentioned included understanding that there are individual differences between students, both in terms of their academic performance and in their behavior; as well as incorporating religious principles such as praying and moral education into classroom management (labeled "God").Each participant's interview was coded for the presence or absence of each of these 26 strategies.

\section{RESULTS}

The first research question asked, what strategies do teachers believe are effective for managing student behavior before training and after training. The classroom management strategies are presented in Table 1. Table 1 includes the percentage of participants who mentioned that strategy in their pre-test interview before the in-service training and in their post-test interview after the in-service training. The difference in the percentage of respondents who mentioned that strategy before and after the inservice training was calculated, with a positive value indicating that more participants mentioned the strategy after training and a negative value indicating that more participants mentioned the strategy before the training. 
Table 1: Teachers Knowledge of Strategies for Effective Classroom Management Before and After Training.

\begin{tabular}{|c|c|c|c|c|}
\hline Strategy & Description & $\begin{array}{l}\text { Before } \\
\text { Training } \\
\end{array}$ & $\begin{array}{l}\text { After } \\
\text { Training }\end{array}$ & Difference \\
\hline $\begin{array}{l}\text { Reactive } \\
\text { Always Enforce Rule }\end{array}$ & Ensure that misbehaving students receive appropriate consequences after every misbehavior. & $20 \%$ & $75 \%$ & $55 \%$ \\
\hline $\begin{array}{l}\text { Remind Rule } \\
\text { Counsel }\end{array}$ & $\begin{array}{l}\text { A warning to remind students of the rules. } \\
\text { Advise students who frequently misbehave. Learn their problems and provide guidance. }\end{array}$ & $\begin{array}{l}10 \% \\
50 \%\end{array}$ & $\begin{array}{l}40 \% \\
65 \%\end{array}$ & $\begin{array}{l}30 \% \\
15 \%\end{array}$ \\
\hline Fairness & Enforce all the rules to all students equally. & $5 \%$ & $15 \%$ & $10 \%$ \\
\hline $\begin{array}{l}\text { Involve Parents } \\
\text { Punishment } \\
\text { Negative Punishment }\end{array}$ & $\begin{array}{l}\text { Include parents in behavioral management strategies. } \\
\text { Only mentioned the word "punishment" without explaining what was meant by punishment. } \\
\text { When students misbehave, take away something they enjoy such as break time. }\end{array}$ & $\begin{array}{l}15 \% \\
45 \% \\
30 \%\end{array}$ & $\begin{array}{l}15 \% \\
40 \% \\
25 \%\end{array}$ & $\begin{array}{l}0 \% \\
-5 \% \\
-5 \%\end{array}$ \\
\hline $\begin{array}{l}\text { Shouting } \\
\text { Physical Punishment }\end{array}$ & $\begin{array}{l}\text { Shout at misbehaving students. } \\
\text { Physical punishment, but no pain was involved, such as standing up or sweeping the compound. }\end{array}$ & $\begin{array}{l}15 \% \\
45 \%\end{array}$ & $\begin{array}{l}10 \% \\
20 \%\end{array}$ & $\begin{array}{l}-5 \% \\
-25 \%\end{array}$ \\
\hline Time Out & Send misbehaving student out of the classroom. & $30 \%$ & $5 \%$ & $-25 \%$ \\
\hline Beating & Beating or flogging students for misbehavior. & $45 \%$ & $10 \%$ & $-35 \%$ \\
\hline $\begin{array}{l}\text { Proactive } \\
\text { Set Rules } \\
\text { Prepare well } \\
\text { Extra Activities } \\
\text { Consequences } \\
\text { Active involvement }\end{array}$ & $\begin{array}{l}\text { Set clear rules, either for the students or together with the students. } \\
\text { Thoroughly prepare for lessons so each class runs smoothly. } \\
\text { Give extra activities for learners when they finish work so they do not misbehave in spare time. } \\
\text { Discuss the consequences of breaking the rules and misbehavior. } \\
\text { Plan interesting, engaging lessons that encourage learners to be actively involved. }\end{array}$ & $\begin{array}{l}15 \% \\
15 \% \\
25 \% \\
20 \% \\
50 \%\end{array}$ & $\begin{array}{l}80 \% \\
60 \% \\
45 \% \\
40 \% \\
70 \%\end{array}$ & $\begin{array}{l}65 \% \\
45 \% \\
20 \% \\
20 \% \\
20 \%\end{array}$ \\
\hline Respect students & Show students respect and/or show them love. & $45 \%$ & $50 \%$ & $5 \%$ \\
\hline Rewards & Provide tangible rewards for good behavior. & $10 \%$ & $15 \%$ & $5 \%$ \\
\hline $\begin{array}{l}\text { Role Model } \\
\text { Parents } \\
\text { Monitor Learners } \\
\text { Rationale for Rules } \\
\text { Verbal Rewards } \\
\text { Clear Expectations }\end{array}$ & $\begin{array}{l}\text { The teacher models appropriate behavior for students. } \\
\text { Involve the parents in strategies for classroom management. } \\
\text { Closely watch students to ensure that they are on task and not tempted to misbehave. } \\
\text { Discuss the reason for the rules; why a student should/should not behave in a certain way. } \\
\text { A verbal statement encouraging students who are behaving properly. } \\
\text { Provide clear guidelines and routines so learners know expectations for behavior in the class. }\end{array}$ & $\begin{array}{l}35 \% \\
15 \% \\
30 \% \\
30 \% \\
15 \% \\
40 \%\end{array}$ & $\begin{array}{l}35 \% \\
15 \% \\
25 \% \\
25 \% \\
10 \% \\
30 \%\end{array}$ & $\begin{array}{l}0 \% \\
5 \% \\
-5 \% \\
-5 \% \\
-5 \% \\
-10 \%\end{array}$ \\
\hline $\begin{array}{l}\text { Miscellaneous } \\
\text { God } \\
\text { Individual Difference }\end{array}$ & $\begin{array}{l}\text { Any mention of God, prayer, religion, or morals as a strategy for improving student behavior. } \\
\text { Understanding differences between learners, both academically and in their behavior. }\end{array}$ & $\begin{array}{l}45 \% \\
45 \%\end{array}$ & $\begin{array}{l}45 \% \\
35 \%\end{array}$ & $\begin{array}{l}0 \% \\
-10 \%\end{array}$ \\
\hline
\end{tabular}


Before training, the two most frequent classroom management strategies were counseling and active involvement of students in lessons $(50 \%$ of participants mentioned this strategy). The next most frequent classroom management strategies were punishment, physical punishment, beating, as well as respecting students, understanding individual differences, and God $(45 \%$ of participants). After training, the frequency of teachers who suggested counseling and active involvement increased, whereas those who suggested physical punishment and beating decreased.

The strategies that showed the largest increase from pre-test to post-test consisted of setting rules, consistently enforcing rules, and preparing lessons well. After the in-service training, the most frequently suggested classroom management strategies included setting rules $(80 \%)$, consistently enforcing rules $(75 \%)$, active involvement of students in lessons
(70\%), counseling students $(65 \%)$, preparing lessons well $(60 \%)$, and respecting students $(50 \%)$. Note that each of these strategies except for counseling is a proactive strategy for preventing misbehaviors. Thus, teachers greatly increased their knowledge about strategies that are effective in preventing misbehavior in the classroom.

The first research hypothesis stated that there is no significant effect of training on the total number of strategies that teachers suggest for managing student behavior. To analyse this hypothesis, the number of classroom management strategies that participants mentioned was summed to get a total score for both the pre-test interview and the post-test interview. Then a one-tailed correlated-samples ttest was conducted comparing the pre-test score to the post-test score. The results are found in Table 2.

Table 2: Correlated samples t-test comparing number of strategies for classroom management.

\begin{tabular}{llllll}
\hline & $\begin{array}{l}\text { Number of } \\
\text { Strategies }\end{array}$ & $\mathrm{t}$ & $\mathrm{df}$ & $\mathrm{p}$ & Decision \\
\hline Before Training & 7.60 & 1.86 & 19 & .039 & Significant \\
After Training & 9.25 & & & & \\
\hline
\end{tabular}

As can be seen from Table 2, the t-test was significant. Therefore, there is a significant effect of training on the number of strategies for managing student behavior. Before the in-service training, teachers mentioned an average of 7.60 strategies for managing student behavior. After the in-service training, teachers suggested an average of 9.35 strategies. Therefore, the inservice training added an average of about 1.75 additional classroom management strategies to teachers' repertoire.
The second research hypothesis stated that there is no significant effect of training on the number of proactive strategies that teachers suggest for managing student behavior. A twotailed correlated-samples t-test was conducted to compare the frequency of proactive strategies that were suggested before the in-service training to the frequency suggested after the in-service training. Table 3 illustrates that the result of the ttest was significant

Table 3: Correlated samples t-test comparing number of proactive strategies for classroom management.

\begin{tabular}{lccccl}
\hline & $\begin{array}{l}\text { Number of } \\
\text { Strategies }\end{array}$ & $\mathrm{t}$ & $\mathrm{df}$ & $\mathrm{p}$ & Decision \\
\hline Before Training & 3.30 & 2.92 & 19 & .008 & Significant \\
After Training & 4.85 & & & & \\
\hline
\end{tabular}


Therefore, there is a significant effect of training on the number of proactive strategies for managing student behavior. Before the in-service training, teachers mentioned an average of 3.30 proactive strategies. After the in-service training, teachers suggested an average of 4.85 proactive strategies. Therefore, the in-service training provided an average of about 1.5 additional proactive classroom management strategies to teachers' repertoire.

The third research hypothesis stated that there is no significant effect of training on the number of reactive strategies that teachers suggest for managing student behavior. Again, a two-tailed correlated-samples t-test was conducted to compare the frequency of reactive strategies that were suggested before the inservice training to the frequency suggested after the in-service training.

As can be seen from Table 4, the t-test result was not significant. Therefore, the inservice training did not change the number of reactive strategies that teachers believed were effective in managing classroom behavior.

Table 4: Correlated samples t-test comparing number of reactive strategies for classroom management.

\begin{tabular}{lccccc} 
& $\begin{array}{l}\text { Number of } \\
\text { Strategies }\end{array}$ & $\mathrm{t}$ & $\mathrm{df}$ & $\mathrm{p}$ & Decision \\
\hline Before Training & 3.10 & 0.23 & 19 & .821 & Not Significant \\
After Training & 3.20 & & & & \\
\hline
\end{tabular}

\section{DISCUSSION}

The purpose of this study was to determine the effectiveness of in-service training on teachers' knowledge of effective classroom management strategies. This study found that a one-day in-service training was effective in increasing the number of strategies that teachers believe are effective for classroom management. Specifically, the number of proactive strategies that teachers believe are effective for classroom management significantly increased after training, whereas the number of reactive strategies remained unchanged. This finding is consistent with that of Marzano and colleagues (2003) who stated that teachers can become more effective classroom managers through awareness of and training in effective classroom management techniques.

Frequent classroom management strategies suggested before training were punishment, physical punishment, and beating. After training, the frequency of teachers who suggested counseling and active involvement of students in lessons increased, whereas those who suggested physical punishment and beating decreased. The strategies that showed the most increase after the in-service training consisted of setting rules, consistently enforcing rules, and preparing lessons well.

\section{RECOMMENDATIONS}

Since this study found that teachers' management strategies can be modified through a brief one-day training, this training should be replicated with other in-service teachers. Furthermore, pre-service teachers in teachertraining institutions should also receive training about effective classroom management strategies.

A minority of participants suggested involving parents in classroom management. Because students spend most of their time outside of the classroom with their parents, the involvement of parents in improving student behavior should be further investigated.

This study examined teachers' knowledge about effective classroom management strategies, not teachers' actual classroom management practices. Thus, additional research should be conducted to determine whether these changes in knowledge translate into changes in teaching practices. Further research should also determine whether these classroom management practices translate into improved student performance. 


\section{CONCLUSION}

In conclusion, this research study found that teachers' knowledge about effective classroom management strategies can effectively be modified by a brief one-day in-service training. In particular, teachers need training about proactive strategies that can be used to reduce student misbehavior in the classroom. Therefore, additional trainings should be implemented to encourage teachers to use effective classroom management strategies.

\section{REFERENCES}

Borich, G. D., 2007. Effective teaching methods: Research-based practice. New Jersey: Pearson Education Inc.

Curwin, R. L., and Mendler, R. L., 1984. High standards for effective discipline. Educational Leadership. Retrieved from http://www.ascd.org/ASCD/pdf/journals/e d_lead/el_198405_curwin.pdf

Eggen, P. and Kauchak, D., 2004. Educational psychology: Windows on classrooms. Upper Saddle River, NJ: Pearson Prentice Hall.

Marzano, R. J., Marzano, J. S., and Pickering, D. J., 2003. Classroom management that works: Research-based strategies for every teacher. Alexandria, VA: Association for Supervision and Curriculum Development. Retrieved from http://www.ascd.org/publications/books/1 03027.aspx
Slavin, R. E., 2006. Educational psychology: Theory and practice $\left(8^{\text {th }}\right.$ ed.). Boston: Allyn and Bacon.

Tauber, R. T., 2007. Classroom management: Sound theory and effective practice $\left(14^{\text {th }}\right.$ ed.).Westport, CT Praeger Publishers.

van der Sude, P. C., and Tomic, W., 1993. A model for classroom management activities. Education, 113, 439-449.

Wang, M. C., Haertel, G. D., and Walberg, H. J., 1993/94. What helps students learn? Educational Leadership, 74-79.

Yount, W. R., 1996. Created to learn. Nashville: Broadman and Holman Publishing.

Yount, W. R., 1999. Called to teach: An introduction to the ministry of teaching. Nashville: B and $\mathrm{H}$ Publishing. 